\title{
Overwintering of Conidia of Venturia inaequalis and the Contribution to Early Epidemics of Apple Scab
}

\author{
I. J. Holb, Department of Plant Protection, Centre of Agricultural Sciences, University of Debrecen, P.O. Box 36, \\ H-4015 Debrecen, Hungary; B. Heijne, Wageningen University and Research Centre, Applied Plant Research, P.O. \\ Box 200, 6670 AE Zetten, The Netherlands; and M. J. Jeger, Department of Agricultural Sciences, Imperial College \\ of Science, Technology and Medicine, Wye, Ashford, Kent TN25 5AH, UK
}

\begin{abstract}
Holb, I. J., Heijne, B., and Jeger, M. J. 2004. Overwintering of conidia of Venturia inaequalis and the contribution to early epidemics of apple scab. Plant Dis. 88:751-757.

Overwintering of conidia of Venturia inaequalis associated with shoots and buds was determined, and the contribution to early spring epidemics of apple scab was evaluated during three consecutive seasons (1999 to 2001) in the Netherlands. Examinations of shoot samples collected before bud break showed that the percentage of shoots with superficial black fungal mycelia or conidia was above $65 \%$, and the mean number of conidia on a $1-\mathrm{cm}$ piece of shoot length ranged from 581 to 1,033 . However, germination tests showed that the viability of conidia on shoots was less than $1.5 \%$. No macroscopic scab lesions were detected on the scales of dormant buds. However, microscopic examinations of individual bud tissues demonstrated that the number of conidia was $>3,000$ per 100 buds in each year. The mean viability of conidia associated with buds ranged from 0.7 to $1.9 \%$ and from 3.7 to $10.5 \%$ for the outer and inner bud tissues, respectively. Results of field assessments at tight-cluster phenological stage showed that the percentage of infection caused by the viable overwintered conidia ranged from 0.3 to $3.8 \%$ in the various treatments. Our results indicated that conidia were unlikely to overwinter on the surface of shoots or outer bud tissues, where they were exposed to fluctuating environmental conditions, and, consequently, were unlikely to play a role in initiating an early epidemic of apple scab in the spring. However, our results indicated a risk from overwintered conidia in the inner bud tissues arising from a high level of scab the previous autumn. Therefore, orchards with high levels of apple scab, where ascosporic inoculum is much reduced, e.g., by sanitation, should be protected in early spring by means of fungicide treatment at green tip.
\end{abstract}

Additional keywords: epidemiology, scab control

Ascospores of Venturia inaequalis (Cooke) G. Wint., released from pseudothecia on overwintered infected leaves, have long been considered the main source of primary scab inoculum $(8,19)$. However, studies from temperate regions with humid climate indicate that mild winters lead to rapid decomposition of leaves, diminishing the role of ascospores as primary inoculum $(10,16)$. In such cases, primary infection could occur from other sources, such as diseased wood, shoots, or buds infected by scab conidia or mycelia (16). Many older studies reported that conidia could overwinter as scab lesions of wood and young shoots $(9-12,15,16,18,25-27,33,37)$. Some of these studies also warned that conidia could cause symptoms in early spring before the period of ascospore release and infection $(10,11,16,33)$. Recent investigations demonstrated that scab conidia could

Corresponding author: I. J. Holb

E-mail: holb@helios.date.hu

Accepted for publication 15 March 2004.

Publication no. D-2004-0518-01R

(C) 2004 The American Phytopathological Society overwinter mainly in two ways: on the tips of shoots $(21,29-31)$ and associated with bud tissues (4-6). These studies demonstrated that overwintered conidia were viable on shoots or on the inner tissues of buds in early spring. These investigations also concluded that the overwintered conidia could be a primary inoculum source for infection at the earliest growth stage before ascospore infection. However, the exact role of overwintered conidia in initiating an early scab epidemic is poorly understood. Moreover, if there is a risk of early infections by overwintered conidia, then it is not clear what the relation is with subsequent attempts at scab control.

The objectives of this study were (i) to determine the number and the viability of overwintered conidia associated with shoots and buds in a diseased orchard, (ii) to distinguish the effect of overwintered conidia and ascospores on scab infection, and (iii) to evaluate the risk and the consequences of early scab infections by overwintered conidia.

\section{MATERIALS AND METHODS}

Experimental orchard. The study was conducted in an experimental orchard at Randwijk (The Netherlands) during the three consecutive years from 1999 to 2001 . The experimental plot consisted of 32 rows, in which two rows of the apple cultivar Jonagold alternated with two rows of cv. Schone van Boskoop. The eighth tree in each row was a pollinator, cv. Delcorf. Cultivars were grown on M.9 rootstock and pruned as slender spindles. Trees were grown according to the Dutch organic guidelines derived from IFOAM standards (1). The plot was flanked by high windbreaks on the west and the south sides. There were no bordering orchard plots on the remaining sides.

Autumn assessments and potential ascospore dose. Incidence and severity of leaf scab were determined after fruit harvest and before leaf fall in each year. Disease incidence was calculated as the percentage of leaves diseased. Leaf disease severity, a measure of the plant area affected by a disease, was calculated as described previously (17).

The potential ascospore dose (PAD) was calculated according to Gadoury and MacHardy (13). The mean number of scab lesions per leaf $\mathrm{m}^{2}$ at leaf fall (lesion density $=\mathrm{LD}$ ) was recorded at the end of October in 1998, 1999, and 2000. The proportion of the orchard floor covered by leaf litter at bud break (leaf litter density = LLD) was determined in 1999, 2000, and 2001. Observations were carried out in six replicates by examining 200 randomly chosen leaves per plot. Across the 3 years, the fertility index (estimated proportion of lesions that are fertile, f), pseudothecial density (mean number of mature pseudothecia per fertile lesion, PD unit), and ascal density (mean number of asci per pseudothecium, $\mathrm{AD}$ unit) ranged from 0.03 to 0.04 , from 45 to 47 , and from 122 to 125 , respectively. PAD was calculated as the average of the experimental orchard plot.

Field experimental layout. In 1999 , 2000, and 2001, the experimental orchard was divided into two areas in early spring at the dormant bud stage. In rows 11 to 32 , the orchard soil was completely covered by $0.05-\mathrm{mm}$-thick plastic sheets secured to the ground with wire pins (Fig. 1). This area was termed the plastic covered section. In rows 1 to 10 , the soil surface with infected fallen leaves was left uncovered (Fig. 1), providing a source of ascospores. In each year, further experimental treatments were applied to the plastic covered section be- 


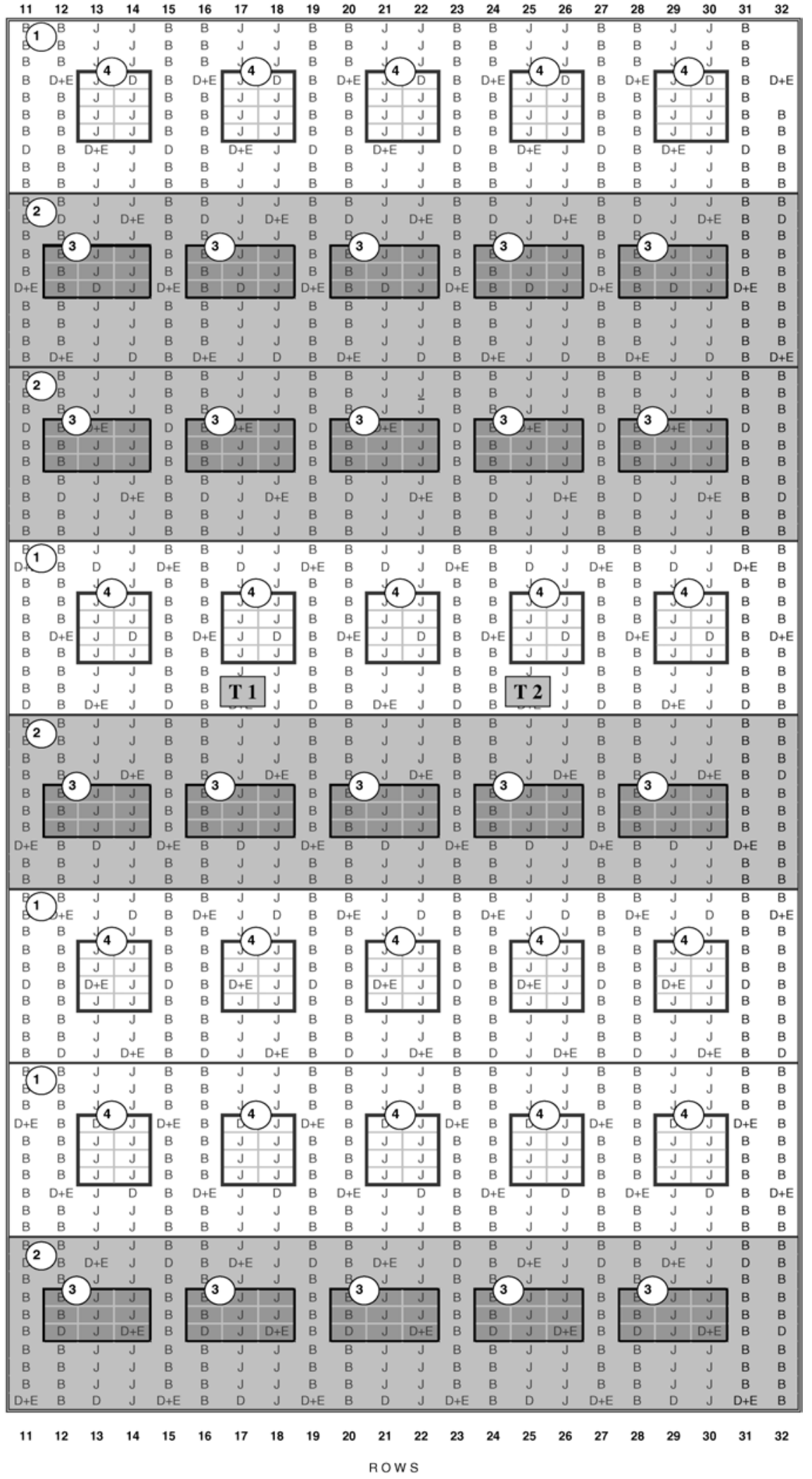

Fig. 1. Experimental design for fungicide, pruning, and plastic bag experiments at Randwijk, The Netherlands, 1999 to 2001. Capital letters in the map are apple cultivars: J = Jonagold, B = Schone van Boskoop, D = Delcorf, D + E = Delcorf + Malus "Everest"; white boxes are plasticcovered sections; dark gray boxes with $\mathrm{T}$ are Burkard volumetric spore traps. Numbers 1 and 2 are plots that were untreated or treated with copper hydroxide plus pyrimethanil before bud break, respectively; number 3 is for replicates of pruning experiment within fungicide-treated sections; number 4 is for replicates of plastic bag treatments within untreated fungicide sections. fore bud break of cv. Jonagold (Fig. 1) Bud break of cv. Jonagold was not earlier than that of other cultivars.

Fungicide experiment. To reduce the number and amount of overwintered conidia and superficial mycelia on shoots and buds, fungicide treatments were applied before bud break. Within each fungicide treatment, further treatments were applied as described below. Fungicide treatments were made in a completely randomized design with two treatments each replicated four times (Fig. 1). Treatments were: (i) untreated or (ii) an application of copper hydroxide (Funguran-OH, a.i. 50\%, Spiess-Urania Chemicals, GmbH, Germany) plus pyrimethanil, a fungicide with systemic properties (Scala, a.i. 400 g/liter, Agrevo Netherlands BV, The Netherlands). Sprays were applied with a handheld spray gun (EMPASS, Huneschans 18-3905 XL Veenendaal, The Netherlands) with a ceramic hollow cone at 1.1 to $1.2 \mathrm{MPa}$ with a volume of 200 liters/ha. Treatments were completed before bud break (25 February, 23 February, and 26 February in 1999, 2000 , and 2001, respectively) to reduce the likelihood that fungicide residues would affect any later infections by ascospores.

Pruning and plastic bag experiments. Within fungicide treatment 2 , a pruning experiment was also prepared with five replicates for each fungicide-treated plot (Fig. 1). Each pruning replicate consisted of nine trees. We assumed from previous observations that most overwintered conidia (about 70 to $80 \%$ ) would be present in the distal one-third of all shoots on the tree (I. J. Holb and B. Heijne, unpublished data). Therefore, the upper third of all shoots was pruned in each of the nine trees and removed from the experimental field immediately before fungicide application.

Within fungicide treatment 1 (untreated), a plastic bag experiment was also prepared with five replicates for each treatment (Fig. 1). Each replicate consisted of eight trees. Four branches of each cv. Jonagold tree were covered with plastic bags. Selected branches with at least 40 buds were covered with clear plastic bags of 40-liter capacity before bud break to reduce as much as possible the opportunity for ascospore infection. Two of four branches were sprayed with distilled water (distilled water treated bags) and the remaining two with conidial suspension of ca. $150 \times 10^{3}$ conidia per ml (artificially treated bags) at bud break, green tip, and early tight cluster phenological stages. Inoculations were made through a small hole on the plastic bag, which was closed immediately after inoculation. Following Mills and LaPlante (28), given the quite low temperatures in springtime, conditions inside the bags were kept at $100 \%$ relative humidity for $48 \mathrm{~h}$ after each inoculation date in order to ensure infection by $\mathrm{co}$ nidia. Plastic bags were firmly secured with ca. $200 \mathrm{ml}$ of water kept in the bottom 
of the bags. Temperature inside the plastic bags was checked on the warmest days and never exceeded $30^{\circ} \mathrm{C}$. After 3-week incubation periods, scab symptoms on leaves of each leaf cluster were checked each day in all plastic bags. All plastic bags were put on the branches before bud break and removed after a 2-week incubation period from the last inoculation date.

Checking airborne ascospores in the plastic covered section. Two Burkard 7day recording volumetric spore traps (Burkard Manufacturing Co. Ltd., Rickmansworth Hertfordshire, England) were operated continuously with the orifice 0.8 $\mathrm{m}$ above ground level from mid-March until the end of April in each year (Fig. 1). The first spore trap was placed in the middle of the row located $21 \mathrm{~m}$ from the border of the source of ascosporic inoculum, and the other was located $45 \mathrm{~m}$ from the border of the source. The spore traps' inlet orifices were directed toward the source. In all years, spore traps were operated at a flow rate of 10 liters $/ \mathrm{min}$. Trapping methods and counting were done as described by Aylor (2).

Sampling shoots and buds for lab examinations. Shoots and dormant flower buds were collected at the end of February in each year and examined for overwintering conidia. Four replicate samples of 50 15-cm-long shoots, and of 200 flower buds excised approximately $2 \mathrm{~mm}$ below the bud scales, were taken for each fungicide treatment.

Laboratory examination for number and viability of overwintered conidia on shoots. First, the percentage of shoots with characteristic superficial black mycelia or conidia was calculated from observations on every shoot. Then, each 15 -cm-long shoot segment was cut into $1-\mathrm{cm}$ pieces, labeled, and separately examined. They were placed in a tube with $5 \mathrm{ml}$ of sterilized rainwater collected on rainy days in an iron bucket placed near the laboratory building. Rainwater was sterilized in a Vernitron 2000M steam sterilizer (Alfa Medical Co., Hempstead, NY) at $180^{\circ} \mathrm{C}$ for $1 \mathrm{~h}$. Then, samples were incubated at $20^{\circ} \mathrm{C}$ for $1 \mathrm{~h}$, submerged in the water bath of an ultrasonic cleaner (Bransonic Cleaning Equipment Co., Shelton, CT), and sonicated for $10 \mathrm{~min}$. Shoot pieces were removed, and $2 \mathrm{ml}$ of the remained suspension in each tube was centrifuged on an Eppendorf 5414 microcentrifuge (Brinkmann Instrument Inc., Westbury, CT) at $10,000 \mathrm{rpm}$ for $7 \mathrm{~min}$. The pellets were resuspended in $200 \mu \mathrm{l}$ of rainwater by stirring on a vortex shaker. Two 100- $\mu \mathrm{l}$ droplets of suspension per 1-cm shoot segment were placed on microslides and incubated in a moist chamber at $20^{\circ} \mathrm{C}$ for $48 \mathrm{~h}$. The number of conidia per drop and the number of germinated conidia were recorded.

Laboratory examination for number and viability of overwintered conidia associated with buds. Every bud sample was labeled and separately examined. Half of the bud samples were examined by the modified Becker method (4) and the other half by the "bud-pressing" method.

In the modified Becker method, bud samples were dissected by removing the outer bud scales and then the inner tissues. Each dissected part was examined by stereo microscope to detect macroscopic lesions on the bud scales. Outer bud scales and inner tissues were then placed separately into plastic bags with $6 \mathrm{ml}$ of rainwater, immersed in the water bath, and sonicated for $10 \mathrm{~min}$. Suspensions were then filtered through a double layer of cheesecloth into beakers, $2 \mathrm{ml}$ of the suspension was placed in each of three Eppendorf microcentrifuge tubes and centrifuged at $10,000 \mathrm{rpm}$ for $7 \mathrm{~min}$. The supernatant was discarded, and the pellets were resuspended in $100 \mu \mathrm{l}$ of rainwater by stirring on a vortex shaker. Each 100- $\mu$ l suspension was placed on microslides and incubated in a moist chamber at $20^{\circ} \mathrm{C}$ for $48 \mathrm{~h}$. The number of conidia per drop (three droplets per outer or inner bud tissues) and the number of germinated conidia were recorded.

In the bud-pressing method, each bud was pressed gently by hand 30 times into a 100- $\mu$ d droplet of rainwater on microslides. The procedure was repeated for a second and a third droplet, but with greater force. The bud was not smashed, only wetted in the first droplet; therefore, it represented mainly conidia on the outer bud tissues. The bud was smashed with five stronger pressings to the object glass using a glass rod in the second and third droplets; therefore, these represented mainly conidia on the inner bud tissues. Droplets were covered by cover glasses and incubated in a moist chamber at $20^{\circ} \mathrm{C}$ and $100 \%$ relative humidity for $48 \mathrm{~h}$. The number of conidia per bud and the number of germinated (viable) conidia were recorded.

Field assessment in spring. Of the 100 leaf clusters assessed, the number of infected clusters was counted for each treatment replicate when the first symptoms appeared on cv. Jonagold. Disease assessments were made on 1 May, 8 May, and 5 May in 1999, 2000, and 2001, respectively. One hundred leaf clusters were used for scab symptom assessments on the middle tree of each replicate plot of the pruning treatment. The assessed trees were 9, 21, 33,45 , and $57 \mathrm{~m}$ from the border of the source of inoculum (rows 1 to 10). In the

Table 1. Means and standard errors (SE) of autumn scab incidence and severity from 1998 to 2000 and of potential ascospore dose (PAD) estimated for the springs of 1999, 2000, and 2001

\begin{tabular}{|c|c|c|c|c|c|c|c|c|}
\hline & \multicolumn{2}{|c|}{1998} & \multicolumn{2}{|c|}{1999} & \multicolumn{2}{|c|}{2000} & \multicolumn{2}{|c|}{2001} \\
\hline & Mean & SE & Mean & SE & Mean & SE & Mean & SE \\
\hline Autumn scab incidence (\%) & 91.5 & 4.9 & 90.4 & 4.8 & 95.4 & 2.5 & $\ldots$ & $\ldots$ \\
\hline Autumn scab severity (\%) & 22.8 & 5.3 & 31.4 & 6.6 & 35.2 & 7.9 & $\ldots$ & $\ldots$ \\
\hline $\mathrm{PAD} \times 10^{-3}$ & & $\ldots$ & 435.6 & 42.5 & 515.7 & 57.2 & 695.7 & 79.3 \\
\hline
\end{tabular}

same rows, five replicates of 100 leaf clusters were observed on unpruned trees for each untreated and fungicide sprayed plot.

Statistical analyses. All data were subjected to analysis of variance (ANOVA) using Genstat 5 (Numerical Algorithms Group Ltd., Oxford). The effects of year, method (modified Becker or bud pressing), position (conidia on outer or inner bud tissue), and their interactions on the number and viability of conidia associated with buds were determined.

In the spring assessments, the number of infected clusters for each fungicide and pruning treatment replicate was averaged. The number of infected clusters was plotted against distance from the source of inoculum for the fungicide and pruning treatments. Linear, exponential, power, logarithmic, and logistic functions (7) were fitted by maximum-likelihood through iterative nonlinear searching using the Genstat, Fitcurve directive, and tested for goodness-of-fit.

\section{RESULTS}

Autumn assessments and PAD. Mean incidence and severity of leaf scab after fruit harvest and PAD increased over the 3 years, and it was significant at $P=0.05$ in 2001 compared with 1999 or 2000 (Table $1)$. The mean disease incidence and severity were $>90 \%$ and $>20 \%$, respectively, in each year. The mean estimates of potential ascospore dose increased from about 400 to $700 \times 10^{3}$ ascospores per $\mathrm{m}^{2}$ of orchard floor at the beginning of each year (Table 1). PAD measurements suggested that heavy ascospore populations were to be expected from the infected, fallen leaves each spring.

Number and viability of overwintered conidia associated with shoots and buds. Visual examination of the collected shoots showed that the percentage with superficial scab was $>65 \%$ in each year (Table 2). Microscopic examination showed that the mean number of conidia on a $1-\mathrm{cm}$ piece of shoot surface ranged from 581 to 1,033 . However, germination tests showed that the viability of conidia on shoots was less than $1.5 \%$.

No scab lesions were detected on the bud scales. However, microscopic examination detected large numbers of conidia associated with buds (Table 2). In some cases, the total number of conidia reached almost 5,000 per 100 buds, with 60 to $85 \%$ of the total number of conidia found on the outer bud tissues in each year compared 
with the inner bud tissues (Table 2). The difference in numbers of conidia on the outer versus inner bud tissues was significant at $P \leq 0.001$ (Table 3). However, mean viability of conidia associated with buds was greater on the inner bud tissues (Table 2), ranging from 0.7 to $1.9 \%$ for the outer and from 3.7 to $10.5 \%$ for the inner bud tissues. The difference in viability was significant at $P \leq 0.001$ (Table 3 ).

The modified Becker and bud-pressing methods gave similar numbers of conidia on both outer and inner bud surfaces (Table 2). In some cases, bud pressing resulted in higher mean numbers of conidia on the outer bud tissues, but overall, evaluation method had no significant effect either on the total number of conidia or on the number of viable conidia associated with buds (Table 3). Interactions between main factors were not significant at $P=0.05$.

Spring aerial ascospore concentration in the plastic covered section. Data collected by the two spore traps situated at 21 and $45 \mathrm{~m}$ from the source of inoculum showed a distinct decrease with distance of the aerial concentration of ascospores in each year (Table 4). The airborne ascospore concentration decreased by at least one-tenth at $45 \mathrm{~m}$ compared with concentrations at $21 \mathrm{~m}$ from the source of inoculum. Often, no ascospores were detectable at $45 \mathrm{~m}$ from the source.

Fungicide and pruning treatments in spring. The number of infected clusters decreased with distance from the source of inoculum for all treatments in each year (Fig. 2). Of the functions tested, number of infected clusters as a function of logarith- mic distance provided the best fit to the data of the treatments in all cases. The level of infection decreased in the order of untreated, fungicide treated, and fungicide treated with pruning. Nonlinear regression analyses indicated that the curves for the untreated and fungicide with pruning treatments differed significantly at $P \leq$ 0.05 within the different years (statistical data not shown). However, the difference in response between the untreated and fungicide with pruning treatments was similar across years (Fig. 2). These differences represented the percentage of infection caused by overwintered conidia, which we estimated to range from 1.4 to $3.8 \%$.

Plastic bag treatments in spring. No symptoms were found either in the artificially inoculated or distilled water treated bags at the inoculation date corresponding to the bud break phenological stage. Infection was low in the inoculated or distilled water treated bags at the inoculation dates of green tip and early tight cluster. For both inoculation dates, shoots in inoculated bags had 5 to $20 \%$ of the leaf clusters within the bag infected (data not shown), which confirmed that conditions were sufficient for infection to occur in the plastic bags. For distilled water bags treated at green tip, symptoms were detected on shoots in the bags after a 3-week incubation period. However, the mean number of infected clusters was low, ranging from 0.3 to 0.8 per 100 leaf clusters. No symptoms were found at the inoculation date of early tight cluster in the distilled water treated plastic bags after a 3-week incubation period. The two treatments differed significantly at the green tip and early tight cluster inoculation dates $(P=0.022$ and $P$ $\leq 0.001$, respectively).

\section{DISCUSSION}

Three main sources of conidial inoculum may be responsible for early spring scab infections: diseased wood, shoots,

Table 3. Analysis of variance for the total and viable overwintered conidia of Venturia inaequalis associated with buds

\begin{tabular}{|c|c|c|c|c|c|}
\hline \multirow{2}{*}{$\begin{array}{l}\text { Source } \\
\text { of variance }\end{array}$} & \multirow[b]{2}{*}{ df } & \multicolumn{2}{|c|}{ Total } & \multicolumn{2}{|c|}{ Viable } \\
\hline & & $\mathbf{M S}^{\mathbf{a}}$ & $P$ value $^{\mathrm{b}}$ & MS & $P$ value \\
\hline Year & 2 & 3,336 & 0.049 & 11.6 & 0.004 \\
\hline Method $^{\mathrm{c}}$ & 1 & 1,024 & 0.289 & 6.64 & 0.115 \\
\hline Position $^{\mathrm{d}}$ & 1 & 51,596 & $<0.001$ & 15.4 & $<0.001$ \\
\hline Residual & 72 & 909 & $\ldots$ & 2.1 & $\ldots$ \\
\hline
\end{tabular}

a Mean square.

b Significant $F$ probability values: nonsignificant at $P \geq 0.05$.

${ }^{c}$ Two methods were used to determine the number and viability of conidia associated with buds: modified Becker method according to Becker (4), and bud-pressing method.

${ }^{d}$ Number of conidia on outer or on inner bud tissues.

Table 2. Number and viability of overwintered conidia of Venturia inaequalis before bud break (1999 to 2001)

\begin{tabular}{|c|c|c|c|c|c|c|c|c|c|}
\hline & \multicolumn{3}{|c|}{1999} & \multicolumn{3}{|c|}{2000} & \multicolumn{3}{|c|}{2001} \\
\hline & Total $^{\mathbf{a}}$ & Viable & Viability (\%) & Total & Viable & Viability (\%) & Total & Viable & Viability (\%) \\
\hline \multicolumn{10}{|c|}{ Black shoot ${ }^{b}$} \\
\hline Mean & 66 & $\ldots$ & $\ldots$ & 67 & $\ldots$ & $\ldots$ & 67 & $\ldots$ & $\ldots$ \\
\hline $\mathrm{SE}$ & 0.7 & $\ldots$ & $\ldots$ & 0.8 & $\ldots$ & $\ldots$ & 0.1 & $\ldots$ & $\ldots$ \\
\hline \multicolumn{10}{|c|}{ Conidia/shoot ${ }^{\mathrm{c}}$} \\
\hline Mean & 695 & 9.5 & 1.4 & 1,033 & 9.8 & 0.9 & 581 & 2.1 & 0.4 \\
\hline $\mathrm{SE}$ & 10.6 & 1.5 & $\ldots$ & 79 & 0.9 & $\ldots$ & 45 & 0.1 & $\ldots$ \\
\hline \multicolumn{10}{|c|}{ Bud (outer) ${ }^{d}$} \\
\hline BEM $^{\mathrm{e}}$ & 2,536 & 45.3 & 1.8 & 2,638 & 42.8 & 1.6 & 3,622 & 24 & 0.7 \\
\hline $\mathrm{SE}$ & 53.2 & 5.5 & $\ldots$ & 11.2 & 6.2 & $\ldots$ & 65.2 & 4.2 & $\ldots$ \\
\hline $\mathrm{BPM}^{\mathrm{f}}$ & 2,689 & 50.2 & 1.9 & 2,786 & 43.9 & 1.6 & 3,786 & 25.9 & 0.7 \\
\hline SE & 69.5 & 6.9 & $\ldots$ & 22.6 & 7.9 & $\ldots$ & 85.3 & 6.5 & $\ldots$ \\
\hline \multicolumn{10}{|c|}{ Bud (inner) ${ }^{\mathrm{d}}$} \\
\hline BEM & 959 & 65 & 6.8 & 583 & 61.2 & 10.5 & 1,335 & 58 & 4.3 \\
\hline SE & 15.3 & 3.6 & $\ldots$ & 23.5 & 5.8 & $\ldots$ & 42.6 & 6.8 & $\ldots$ \\
\hline BPM & 1,045 & 68 & 6.5 & 601 & 62.4 & 10.4 & 1,226 & 46 & 3.7 \\
\hline SE & 20.4 & 4.1 & $\ldots$ & 31.9 & 4.9 & $\ldots$ & 39.5 & 4.8 & $\ldots$ \\
\hline \multicolumn{10}{|c|}{ Bud $(\text { outer }+ \text { inner })^{d}$} \\
\hline BEM & 3,495 & 110 & 3.2 & 3,221 & 104 & 3.2 & 4,957 & 82 & 1.7 \\
\hline $\mathrm{SE}$ & 67.9 & 8.8 & $\ldots$ & 33.5 & 11.7 & $\ldots$ & 106 & 10.8 & $\ldots$ \\
\hline BPM & 3,734 & 118 & 3.2 & 3,387 & 106 & 3.1 & 5,012 & 71.9 & 1.4 \\
\hline $\mathrm{SE}$ & 89.5 & 10.7 & $\ldots$ & 54.1 & 12.2 & $\ldots$ & 124 & 10.9 & $\ldots$ \\
\hline
\end{tabular}

a Sum of the mean number of total and viable conidia.

b Mean percentage of shoots covered with superficial scab.

${ }^{c}$ Mean number of total and viable conidia on a $1-\mathrm{cm}$ piece of shoot.

${ }^{\mathrm{d}}$ Mean number of total and viable conidia on the outer and inner tissues of buds per 100 buds.

e Modified Becker method.

f Bud-pressing method. 
and buds. Scab lesions were not detected on wood of apple trees in the orchard in the spring. It is likely that Dutch climate is not favorable for the overwintering of scab lesions on wood. However, in this study, many shoots with superficial black mycelia or conidia were found in early spring (Table 2). Results of microscopic examinations demonstrated that large numbers of Spilocaea pomi conidia were detected on the surface of shoots in all years (Table 2). However, the viability of conidia on shoots was less than $1.5 \%$. These results were in agreement with studies in New York State $(4,6)$ that reported that few or no conidia survived on the exposed surface of shoots. However, in the Lake Constance region of Germany, it was found that the germination rate of conidia on shoots with superficial scab was generally $12 \%$ on susceptible apple cultivars $(20,29-31)$. The differences found in these studies may be due to different inoculum levels and/or environmental conditions in the orchards, as yet unknown.

Large numbers of conidia were found on the outer surface of buds (Table 2), but viability was less than $2 \%$, similar to the viability on shoots. In the past, Louw (23) detected nonviable conidia on the surface of the overwintered buds in South Africa. Becker (4) and Becker et al. (6) also found that few or no conidia of apple scab overwintered on the outer surface of dormant buds. The results from this study and the others cited suggest that conidia are unlikely to overwinter on the surface of apple tissues (shoots or outer bud tissues), where they are exposed to fluctuating environmental conditions, and consequently are unable to play a role in the early epidemic of apple scab.

The mean number of conidia on inner bud tissues was half to one-third that on outer bud tissues (Table 2). However, the viability of conidia on the inner bud tissues was 3 to 10 times higher in early spring than viability on the outer bud tissues. In the past, Bagenal et al. (3), Salmon and Ware (33), and Jeffrey (18) found viable conidia inside dormant buds which could infect bud scales. Becker (4) and Becker et al. (6) also found conidia in dormant buds but with viability higher than our results. Moreover, all these studies found bud scales with macroscopic scab lesions. We did not detect macroscopic scab lesions in our bud samples, although large numbers of conidia were found by microscopic examination. Possible explanations in our case are that conidia simply had not infected bud tissues in the previous season, or that they might have infected the inner bud tissues and caused microscopic lesions but the conditions were not sufficient at certain periods for producing macroscopically visible lesions. However, our data in combination with those other reports indicate that conidia are likely to overwinter and remain viable mainly under the shielding provided by the inner bud tissues.

In our study, results of the plastic bag treatments suggest that the overwintered conidia infected young green tissues, probably from the inner tissues of the buds, as also supposed by Becker (4) and Becker et al. (6). However, the lesioncausing efficiency in the plastic bags was low $(<1 \%)$. In contrast, the percentage of infection by overwintered conidia was $>3 \%$ in some cases in the fungicide and pruning treatments. This implies that conditions might not be optimal in the plastic bag for infection by overwintered conidia.

It is possible that fungicide residues following the pre-bud burst application could have been transferred to leaves and re- duced ascospore viability during infection periods, affecting the percent mortality of ascospores. We did not make direct residue measurements, but we think the chance for this was quite low. First, there was a one and a half month interval between the fungicide application and the first infection (3 weeks before the first assessment date). Second, recent studies showed that residues of pyrimethanil on tomato leaves and fruits declined by half within 4 and 6 days and reached the minimal detection level in the first 10 and 14 days, probably due to photodegradation of the fungicide $(14,32)$.

Results of the plastic bag treatment showed that possible infections by overwintered conidia could start at the green tip phenological stage. Kennel (21) demonstrated that the first green parts exposed in spring were sepals; therefore, they could be infected first. Sepals are a very important infection source for young fruits and could provide significant inoculum for secondary infections. Becker et al. (6) showed that sepals could be infected by overwintered conidia as early as green tip. Therefore, if large numbers of overwintered conidia associated with buds occur in an apple orchard, it is important to prevent early infection. Recent scab warning systems in most European countries recommend an application of protectant fungicide spray against apple scab before bud break. This fungicide spray is applied for treating the superficial scab on shoots $(20,30,31)$, shoot basal scab (22), and other conidial sources on the surface of tree tissues $(10,16,34)$. Our findings indicate that sprays in spring, before bud break, may not be effective under Dutch conditions because wood scab is not common in the Dutch provinces and viability of overwintered conidia on the surface of apple

Table 4. Number of Venturia inaequalis ascospores per $\mathrm{m}^{3}$ collected by two spore traps situated at 21 and $45 \mathrm{~m}$ from the source of inoculum from $16 \mathrm{March}$ until 26 April (1999 to 2001, Randwijk, The Netherlands)

\begin{tabular}{|c|c|c|c|c|c|c|c|c|}
\hline \multicolumn{3}{|c|}{1999} & \multicolumn{3}{|c|}{2000} & \multicolumn{3}{|c|}{2001} \\
\hline Release event & Trap $1(21 \mathrm{~m})$ & Trap 2 (45 m) & Release event & Trap 1 (21 m) & Trap 2 (45 m) & Release event & Trap 1 (21 m) & Trap $2(45 \mathrm{~m})$ \\
\hline 23 March & 30.2 & 0 & 16 March & 35.2 & 0 & 29 March & 384.3 & 43.6 \\
\hline $24 \mathrm{March}$ & 69.8 & 0 & 17 March & 230.7 & 12.9 & 4 April & 550.9 & 109.9 \\
\hline 25 March & 161.2 & 0 & 18 March & 44.7 & 0 & 5 April & 83.5 & 0 \\
\hline 26 March & 231.7 & 25.8 & 20 March & 38.4 & 0 & 6 April & 234.2 & 33.4 \\
\hline 27 March & 33.4 & 0 & $22 \mathrm{March}$ & 57.2 & 0 & 7 April & 283.9 & 52.8 \\
\hline 30 March & 14.9 & 0 & 24 March & 27.8 & 0 & 8 April & 150.3 & 0 \\
\hline 3 April & 102.2 & 0 & 26 March & 109.3 & 0 & 10 April & 568.4 & 112.2 \\
\hline 4 April & 315.5 & 32.4 & 27 March & 187.9 & 26.9 & 14 April & 401.2 & 100.3 \\
\hline 5 April & 611.5 & 57.2 & $28 \mathrm{March}$ & 259.7 & 42.9 & 15 April & 267.6 & 28.9 \\
\hline 6 April & 97.5 & 0 & 29 March & 48.3 & 0 & 17 April & 250.5 & 27.9 \\
\hline 7 April & 261.2 & 0 & 3 April & 11.7 & 0 & 18 April & 70.9 & 0 \\
\hline 17 April & 48.1 & 0 & 5 April & 29.8 & 0 & 19 April & 63.8 & 0 \\
\hline 21 April & 183.6 & 17.6 & 8 April & 19.8 & 0 & 25 April & 283.9 & 52.8 \\
\hline 22 April & 55.1 & 0 & 12 April & 56.3 & 0 & & & \\
\hline \multirow{8}{*}{23 April } & 27.9 & 0 & 13 April & 584.5 & 119.2 & & & \\
\hline & & & 14 April & 228.2 & 26.9 & & & \\
\hline & & & 15 April & 147.3 & 16.7 & & & \\
\hline & & & 16 April & 317.3 & 61.9 & & & \\
\hline & & & 17 April & 111.2 & 0 & & & \\
\hline & & & 18 April & 43.9 & 0 & & & \\
\hline & & & 22 April & 139.6 & 13.7 & & & \\
\hline & & & 23 April & 69.8 & 0 & & & \\
\hline
\end{tabular}



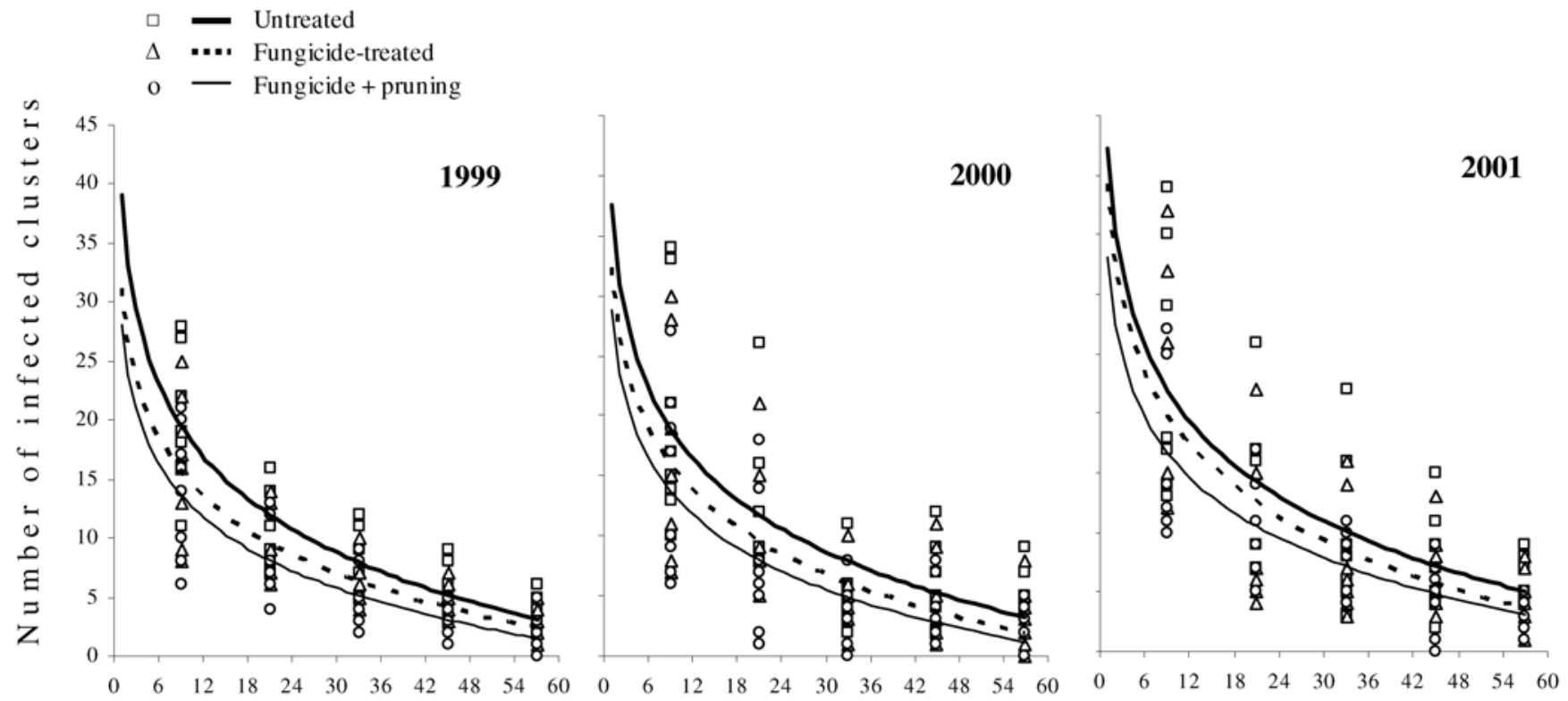

Distance from the source of inoculum (m)

\section{9}

$$
\begin{aligned}
& \mathbf{Y}_{\mathbf{U}}=-8.89 \ln (\mathrm{x})+39.1 \\
& \mathbf{Y}_{\mathrm{F}}=-7.09 \ln (\mathrm{x})+31.1 \\
& \mathbf{Y}_{\mathrm{FP}}=-6.58 \ln (\mathrm{x})+28.2
\end{aligned}
$$

$\begin{array}{ll} & 2000 \\ \mathrm{R}^{2}=0.85 & \mathbf{Y}_{\mathbf{U}}=-8.47 \ln (\mathrm{x})+37.5 \\ \mathrm{R}^{2}=0.83 & \mathbf{Y}_{\mathrm{F}}=-7.54 \ln (\mathrm{x})+32.4 \\ \mathrm{R}^{2}=0.79 & \mathbf{Y}_{\mathrm{FP}}=-6.82 \ln (\mathrm{x})+28.7\end{array}$

$\mathrm{R}^{2}=0.66$
$\mathrm{R}^{2}=0.63$
$\mathrm{R}^{2}=0.62$
2001

$$
\begin{aligned}
& \mathbf{Y}_{\mathbf{U}}=-9.02 \ln (\mathrm{x})+42.2 \\
& \mathbf{Y}_{\mathbf{F}}=-8.81 \ln (\mathrm{x})+39.2 \\
& \mathbf{Y}_{\mathbf{F P}}=-7.42 \ln (\mathrm{x})+33.1
\end{aligned}
$$

$\mathrm{R}^{2}=0.66$

$\mathrm{R}^{2}=0.69$

$\mathrm{R}^{2}=0.73$

Fig. 2. Mean numbers of infected clusters for five replicates of untreated (U), fungicide treated $(\mathrm{F})$, and fungicide treated combined with pruning (FP) experiments in spring 1999, 2000, and 2001.

tissues was low. If conidia overwinter within the inner tissues of buds, then a protectant spray before bud break would not kill overwintered conidia because they are protected by bud scales. A better strategy would be to prevent overwintered conidial infection directly after bud break by a fungicide spray at green tip. However, the risk of overwintered conidial infection is likely to be high in highly diseased orchards with susceptible varieties, as was the case in our studies. In many cases, conditions that favor conidial overwintering will also favor ascosporic inoculum. However, in mild winters, leaf decomposition can be rapid and thus PAD is naturally reduced, whereas bud survival of conidia may not be affected. Several studies have aimed to eliminate ascosporic inoculum by sanitation treatments $(24,35,36)$. Such treatments can include shredding, urea fertilization, flaming, removal of leaves, or some combination of these strategies, aimed at destroying the overwintering pseudothecia. In such a situation, conidial inoculum overwintering within buds might assume a greater importance than ascospores. Therefore, in these orchards, control measures aimed at conidia will probably be needed, but it seems that growers have to know before bud break the number and viability of overwintered conidia in their orchards. This study used two methods to examine the number and viability of overwintering conidia. Both evaluation methods were reliable and the results of the methods comparable. The bud-pressing method is simpler and quicker, although still laborious, and therefore we recommend it to plant protection advisers for detecting the overwintered conidia before bud break.

In conclusion, there is a risk of early scab epidemics initiated by overwintered conidia in orchards where there has been a high incidence of apple scab. However, the risk might be negligible in well-managed commercial orchards where there has been a low incidence of scab the preceding growing season. Results of investigations into the relative significance of overwintered conidia in commercial apple orchards in the Netherlands with various incidences of scab will be reported elsewhere (I. J. Holb, B. Heijne, and M. J. Jeger, unpublished).

\section{ACKNOWLEDGMENTS}

This work was funded by the Netherlands Ministry of Agriculture. We thank Troy B. Wiwczaroski (Centre of Agricultural Sciences, University of Debrecen) and József Gáll (University of Debrecen, Institute of Mathematics and Informatics) for their critical reading of the manuscript and valuable suggestions, and R. H. N. Anbergen for his excellent cooperation in this research. The study was partly supported by the Hungarian Scientific Research Fund (OTKA F043503) and a János Bolyai Research Fellowship awarded to I. Holb.

\section{LITERATURE CITED}

1. Anonymous. 1998. Basic Standards for Organic Production and Processing. TholeyTheley Press, New York.

2. Aylor, D. E. 1993. Relative collection efficiency of Rotorod and Burkard spore samplers for airborne Venturia inaequalis ascospores. Phytopathology 83:1116-1119.

3. Bagenal, N. B., Goodwin, W., Salmon, E. S. and Ware, W. M. 1925. Spraying experiments against scab. J. Mineral Agric. 32:137-149.

4. Becker, C. M. 1990. Overwintering of the anamorph of Venturia inaequalis (Spilocaea pomi) in apple buds and the viability of conidia as affected by discontinuous wetting. Ph.D. thesis. Cornell University, New York.

5. Becker, C. M., and Burr, T. J. 1990. Association of Venturia inaequalis conidia with apple buds. (Abstr.) Phytopathology 80:117.

6. Becker, C. M., Burr, T. J., and Smith, C. A 1992. Overwintering of conidia of Venturia inaequalis in apple buds in New York orchards. Plant Dis. 76:121-126.

7. Campbell, C. L., and Madden, L. V. 1990. Introduction to Plant Disease Epidemiology. John Wiley \& Sons, New York.

8. Childs, L. 1917. New facts regarding the period of ascospore discharge of the apple scab fungus. Oregon Agric. Exp. Stn. Bull. 143:111.

9. Cook, M. T., and Schwarze, C. A. 1917. Apple scab on the twigs. Phytopathology 7:221-222.

10. Cook, R. T. A. 1974. Pustules on wood as sources of inoculum in apple scab and their response to chemical treatments. Ann. Appl. Biol. 77:1-9.

11. Dillion Weston, W. A. R., and Petherbridge, F. R., 1933. Apple and pear scab in East Anglia. J. Pomol. Hortic. Sci. 11:185-198.

12. Dillion Weston, W. A. R., Storey, I. F., and Ives, J. V. 1952. Apple scab in the Wisbech area. Garden Ch. 132:1-195.

13. Gadoury, D. M., and MacHardy, W. E. 1986. Forecasting ascospore dose of Venturia inaequalis in commercial apple orchards. Phytopathology 76:112-118.

14. Garau, V. L., Angioni, A., Del Real, A. A., Russo, M., and Cabras, P. 2002. Disappearance of azoxystrobin, pyrimethanil, cyprodinil, and fludioxonil on tomatoes in a greenhouse. J. 
Agric. Food Chem. 50:1929-1932.

15. Gloyer, W. O. 1937. Evaluation of an orchard experiment on scab control. (Abstr.) Phytopathology 27:129.

16. Hill, S. A. 1975. The importance of wood scab caused by Venturia inaequalis (Cke) Wint. as source of infection for apple leaves in the spring. Phytopathol. Z. 82:216-223.

17. Holb, I. J., Heijne, B., and Jeger, M. J. 2003. Summer epidemics of apple scab: The relationship between measurements and their implications for the development of predictive models and threshold levels under different disease control regimes. J. Phytopathol. 151:335-343.

18. Jeffrey, M. W. 1953. Preliminary investigation into the life cycle of Venturia inaequalis (Cooke) Wint. in South Australia. Aust. J. Agric. Res. 4:415-422.

19. Keitt, G. W., and Jones, L. K. 1926. Studies of the epidemiology and control of apple scab. Univ. Wisc. Agric. Exp. Stn. Res. Bull. 73:1104.

20. Kennel, W. 1981. Zum auftreten von Schorfkonidien auf äußerlich unversehrter Rinde von Apfelzweigen. Mitt. Biol. Bundesanst. Land- Forstwirtsch. Berl.Dahl. 203:117.

21. Kennel, W. 1987. Kelchblätter als erste Objecte für Apfelschorf. Erwerbsobstbau 29(2):36-38.
22. Kennel, W. 1990. Die Überwinterung des Apfelschorfs. Obstbau 8:346-347.

23. Louw, A. J. 1951. Studies on the influence of environmental factors on the overwintering and epiphytology of apple scab (Venturia inaequalis [Cke.] Wint.) in the winter-rainfall area of the Cape Province. Union S. Afr. Dep. Agric. Sci. Bull. 310:1-47.

24. MacHardy, W. E., and Sutton, D. K. 1995. Integrating sanitation practices with fungicide applications to reduce fungicide dose in controlling apple scab. Abstr. 3011/0523 in: Proc. Int. Plant Prot. Congr. XIII.

25. Marsh, R. W., and Walker, M. M. 1932. The scab fungus (Venturia inaequalis) on apple shoots. J. Pomol. Hortic. Sci. 10:71-90.

26. McAlpine, D. 1902. The apple scab fungus causing black spot of apple and pear. Victoria Agric. Dep. J. 1:703-708.

27. McKay, R. 1938. Conidia from infected budscales and adjacent wood as a main source of primary infection with the apple scab fungus Venturia inaequalis (Cooke) Wint. Sci. Proc. Royal Dublin Soc. 21:623-640.

28. Mills, W. D., and LaPlante, A. A. 1951. Diseases and insects in the orchard. Cornell Univ. Ext. Bull. 711:1-5.

29. Moosherr, W. 1990. Untersuchungen zu superfiziellen Schorf und Knopfenschorf (Venturia inaequalis [Cke.] Wint.) beim Apfel. $\mathrm{Ph} . \mathrm{D}$. thesis. Universität Hohenheim, Hohen- heim, Germany.

30. Moosherr, W., and Kennel, W. 1986. Zur epidemiologischen Bedeutung von superfiziellen Zweigschorf bei Apfelbäumen. Mitt. Biol. Bundesanst. Land- Forstwirtsch. Berl.Dahl. 232:212.

31. Moosherr, W., and Kennel, W. 1995. Investigations on superficial apple scab on apple shoots. J. Plant Dis. Prot. 102(2):171-183.

32. Sadlo, S. 2002. Disappearance of pyrimethanil residues on tomato plants. J. Agric. Food Chem. 50:1089-1091.

33. Salmon, E. S., and Ware, M. W. 1931. A new fact in the life history of the apple scab fungus. Garden Ch. 89:437-438

34. Stensvand, A., Amundsen, T., and Semb, L. 1996. Observations on wood scab caused by Venturia inaequalis and $V$. pirina in Norway. Norw. J. Agric. Sci. 10:533-540.

35. Sutton, D. K., and MacHardy, W. M. 1993. The reduction of ascosporic inoculum of Venturia inaequalis by orchard sanitation. (Abstr.) Phytopathology 83:247.

36. Sutton, D. K., MacHardy, W. E., and Lord, W. G. 2000. Effects of shredding or treating apple leaf litter with urea on ascospore dose of Venturia inaequalis and disease buildup. Plant Dis. 84:1319-1326.

37. Swinburne, T. R. 1965. Apple scab infection of young wood of Bramley's seedling trees in Northern Ireland. Plant Pathol. 14:23-25. 